\title{
Disaster literacy among young peatland farmers in Central Kalimantan
}

\author{
Dewi Sinta $^{1 *}$ \\ ${ }^{1}$ Environment Science Program, Postgraduate School, Universitas Padjadjaran, Indonesia
}

\begin{abstract}
The One Million Hectare Peat Clearing Project (PLG) in Central Kalimantan, designed as a rice granary in 1995, has become the door to ecological disasters on peatlands. Canalization that drains the peatlands excessively has sparked fires over the past 23 years, especially during the long dry season. Given the large losses incurred and the high budget for land fire suppression, pre-disaster management is important, one of which is through the concept of disaster literacy. Disaster literacy in this case is a non-structural mitigation approach that focuses on skills and understanding of disasters to reduce disaster risk. This study aims to see the application of the concept of disaster literacy, especially to young peatland farmers who are directly involved in agricultural management in a broad sense through the various existing literatures. The discussion will cover a lot of local wisdom of the community in managing peatlands in relation to the prevention of peatland fires.
\end{abstract}

\section{Introduction}

The clearing of one million hectares of peatlands (PLG) in Central Kalimantan in 1995 with the aim of making Indonesia the world's rice producer has been an ecological disaster for the past 23 years. Although this project was discontinued in 1999 because it was considered to have more negative environmental and social impacts on the local community [1], it has left a degraded landscape, with a network of drainage channels that are not functioning, over-drained and quickly oxidized peat soils, making it vulnerable against fire [2]. Intensive drainage development in the PLG project with a canal system has lowered the groundwater table, causing dry and flammable peatlands [3] - [5].

Peatlands that have been drained and logged a lot are the locations of the most frequent forest fires. This is the main impact due to the destruction of peatlands in Central Kalimantan [6]. In 2015, this province even became the area with the most extensive peatland fires in Indonesia (nearly 200,000 ha), followed by South Sumatra (145,000 ha), West Kalimantan (75,000 ha), Riau (70,000 ha) and Jambi (40,000 ha) [7].

Previous studies have highlighted that the ex-PLG area in Central Kalimantan is now highly fire prone [8] - [10], with implications for loss of carbon storage, biodiversity and other functions of valuable natural resources [11], [12]. Approximately 2.4 million hectares of peatland were damaged due to forest and land fires during June to October 2015 and caused hundreds of trillions of rupiah in losses beyond the calculation of the health, education, germplasm, environment, and other sectors. This loss is much higher compared to a similar incident in 1997 which only caused losses to the state amounting to IDR 60 trillion [13], [14].

On the other hand, land fire disaster management in Indonesia currently focuses more on extinguishing efforts than on the aspect of prevention. If this continues, the country will need a bigger budget to deal with peatland fires. Therefore, it is necessary to strengthen the management of peatland fire disasters, especially at the pre-disaster stage in the form of disaster education aimed at creating disaster-aware communities.

Afrian and Islami (2019) conducted experiments in Langsa City on 1786 people related to increasing disaster mitigation potential by strengthening disaster literacy skills. The results show that the process of increasing disaster information literacy has led to increased community understanding and preparedness for flood disasters in the area [15]. Then Marlyono and Urfan (2019) and Purwandari et al., (2018) have also conducted research related to disaster mitigation learning through geography and educational animation as a source of disaster literacy. The results show a positive role in improving the students' disaster preparedness [16], [17]. On the other hand, public knowledge about disasters in general in some disasterprone areas in Indonesia is still low [18] - [23].

Yuliani (2018) states that forest and land fire disasters have a special method of handling them, especially in the disaster prevention process not only involving aspects of disaster risk reduction but also must be accompanied by community empowerment so that the community becomes the main component in this prevention process [24]. In line with that, Carter (2008) even calls the community as "disaster front" in disaster management because they are the components that best understand the character of the place of residence and the social situation in the disaster area [25]. Community involvement in disaster prevention activities like this is one form of non-physical mitigation, one of which is through disaster literacy, which is the capacity of individuals to read, understand and use the information to make an information policy by following instructions in the context of mitigation, preparedness, response and recovery from disasters [26].

Preventing damage to the peat ecosystem can start with understanding how local people use and manage

\footnotetext{
* Corresponding author: sintasinta1924@gmail.com
} 
their land. Communities who interact intensively with peat ecosystems usually have a legacy of traditional knowledge about peatland management as has been applied by communities in Kalimantan and Sumatra for 200 years [27]. Measurement related to the level of disaster literacy, especially among young peatland farmers who are currently continuing their farming activities, will certainly help the educational process in fire prevention efforts [28], [29]. Therefore, this paper aims to look at the application of the concept of disaster literacy to young peatland farmers in Central Kalimantan based on local knowledge through the various available literature.

\section{Discussion}

\subsection{Concept of Disaster Literacy}

The concept of disaster literacy is adapted from the concept of health literacy initiated in the US since 1974 which has now been recognized for its role in reducing health risks [26]. Disaster risk reduction literacy will empower people to act appropriately when a disaster occurs [30]. The results of Tanaka's research (2005) states that residents of Fukui City, Japan who have better disaster knowledge will be better prepared to face disasters than residents in San Francisco who have lower disaster knowledge [31].

Disaster literacy is defined as an individual's capacity to read, understand and use the information to form an information policy by following instructions in the context of disaster mitigation, preparedness, response and recovery. With this definition and integrating it with Nutbeam's conceptualization of health literacy, Brown et al., (2014) then proposed a disaster literacy model in which knowledge and skills are positioned along a continuum [26]. On the disaster literacy continuum, skills develop from basic (i.e., basic reading and comprehension) to functional (i.e. the ability to follow disaster preparedness, response and messages) to communicative or interactive disaster literacy (i.e. advanced skills involved in the experience of seeking and managing aid disaster-related), and ultimately becomes critical for disaster literacy (i.e. the capacity to analyze disaster-related information, be empowered to overcome obstacles, and take personal control to stay safe, cope with, and recover from disasters). The disaster literacy model can be seen from the following Figure 1.

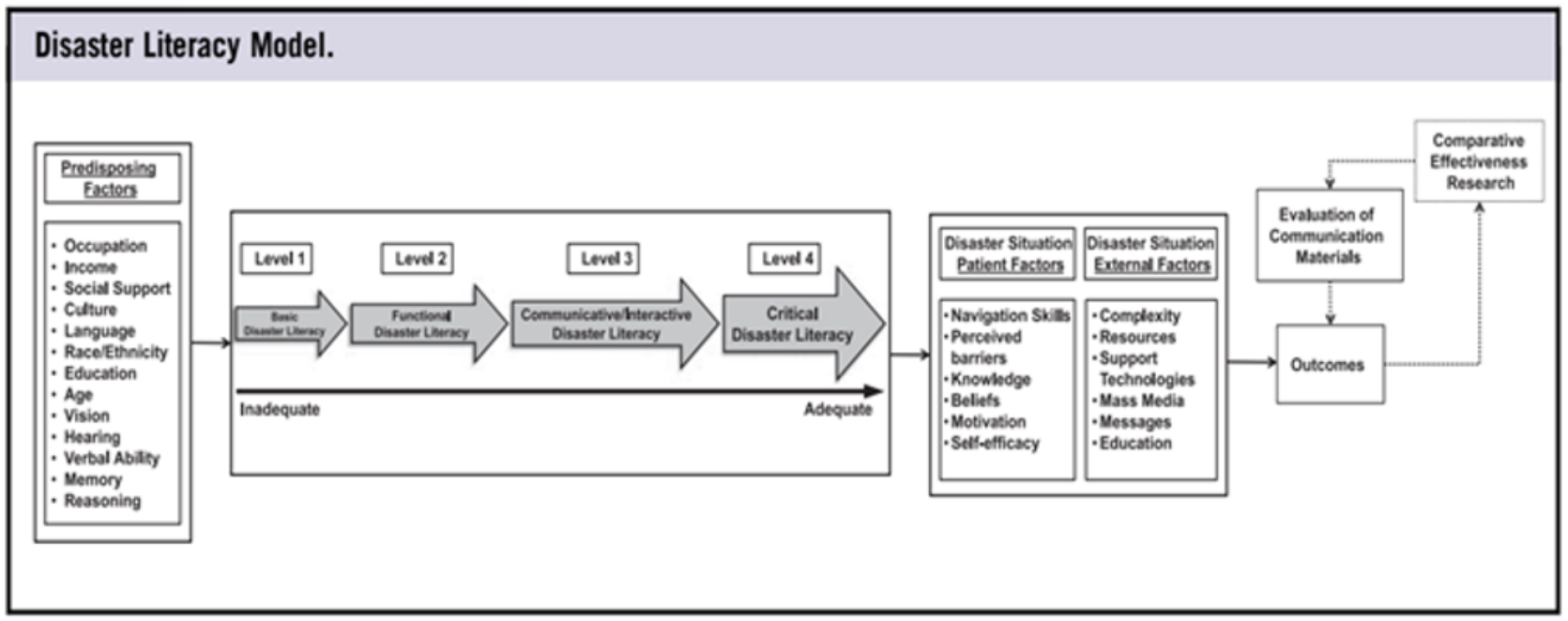

Figure 1. Literacy Model proposed by Brown et al., (2014) [26].

Stage 1 , is the initial stage of literacy, at least the community and individuals are able to read and be able to understand instructions regarding disaster mitigation and preparedness. At this level the capacity tends to be low but is willing to follow instructions related to disaster preparedness, disaster response and recovery messages. Stage 2, is a comprehensive ability related to disaster information, proven by having followed the recommendations and instructions. Although individuals at this stage generally lack experience in the ability to process information, this ability is quite important as a provision for dealing with disasters that can appear suddenly. Stage 3, is the motivation and confidence of individuals to be proactive. At this level the message is well received. Messages can then be modified or added according to familiar things. Messages can differ according to community and individual needs. Stage 4, this stage the individual involvement has gone further. Individuals already understand broader information, understand the situation more broadly, especially those related to environmental and social safety barriers [32].

According to Brown et al., (2014) this disaster literacy model will complement existing models such as CERC, which in this case discusses the ability of individuals to access, understand and respond to these communications. The difference is, the focus of this disaster literacy model is on a progressive movement from basic disaster literacy to greater autonomy, involvement in critical disaster preparedness and recovery activities. Targeted disaster education and training optimizes preparedness and should facilitate movement from one level on the continuum to the next, taking into account each step of the specific knowledge required to prepare for, survive and recover from a disaster. However, when doing so, predisposing and 
situational factors need to be recognized as an influence and are potentially confounding in determining outcome [26].

\subsection{Human Interaction and Peat Ecosystem}

Utilization of peat land for agriculture was initially developed by local communities for family food needs such as rice, sweet potatoes, taro, sago and several horticultural crops such as chilies, eggplant, cucumber, long beans, pumpkin and so on for their own consumption. This utilization is still traditional with a limited area [1]. Small scale land clearing by means of burning in the communities of Kalimantan and Sumatra was carried out around 200 years ago [27]. The cultivation is carried out using shifting cultivation and a system of slash and burn which is commonly known as "swidden agriculture" [33].

Meanwhile, the planting of the Dayak Ngaju community is carried out in groups on a large stretch of land on a small river called the handel system. As for the preparation of the land through controlled burning, namely by making firebreaks in the form of trenches or clearing wood, grass and leaves around the 3-6 meter wide area. In addition, if there is a violation of customary rules, a Jipen or customary fine will be given [34]. And they usually only cultivate seasonal wild rice types without cutting trees due to limited equipment they have [35]. In the Meratus Dayak community there are even 26 varieties of rice that they plant without the need to buy seeds [36]. The types of local rice used are usually rice varieties that are tolerant of acid soils and tidal soils [37].

Akbar's research (2011) on the local wisdom of the Dayak Ngaju people in Central Kalimantan revealed information from traditional leaders regarding the condition of the peat ecosystem before the intervention of outsiders with modern equipment where the forest was dense and the peat soil was always wet even in the dry season, so big fires were rare. Therefore, in the past people had only experience of extinguishing small fires and rarely had experience of extinguishing large fires on a large scale. However, after the technology of chainsaws to cut wood was used, trees in the forest became quickly depleted, open land cover and became prone to fires [33].

Controlled burning according to the local wisdom of the Dayak people is about tools, human resources and methods of burning. If the land for farming has been slashed and dry, burning begins. Before burning, each group member cleaned the tatas or firebreaks [33]. This local wisdom is obtained from the results of continuous trials in adapting to environmental changes. Their long and intensive interaction with this soil type through observation and trial error has developed into local knowledge of farmers in each peatland farming community. Therefore, the use of natural resources and the environment of local communities in the past was still able to maintain the sustainability of the ecological system [38], [39].

The knowledge and wisdom of indigenous peoples is knowledge of how to live well in an ecological community so that it involves how to relate well to all the contents of nature. This knowledge also includes how to treat every part and life of nature in such a way, both to maintain the life of each species and to maintain all life in nature itself. That is why there are various prohibitions or taboos, about how to carry out certain activities in this world: how to do farming, hunting, fishing, cutting trees properly and so on [40]. For example, one of the local wisdom possessed by Bakumpai farmers in tidal land is not only seen in the ability to farm, but also the choice of agricultural location as an effort to anticipate agricultural land which is always overflowing as the characteristics of tidal land type A [38]. The reciprocal relationship between the community and the surrounding ecosystem gives them the ability to manage existing natural resources. It is not surprising that they get a lot of knowledge and values from their experience in dealing with the natural environment around them. For residents who have succeeded in acquiring knowledge and knowing the behavior of nature and its surroundings, they have the potential to be more successful in their daily lives in treating nature [41].

However, human interaction with the ecosystem can always change when there is a change in the configuration of the structure it will affect its structure and function. The causal relationship of the interaction of humans and their very complex ecosystems can be shown through a simple diagram of the basic structure and function of the relationships involved in the following human ecological system model:

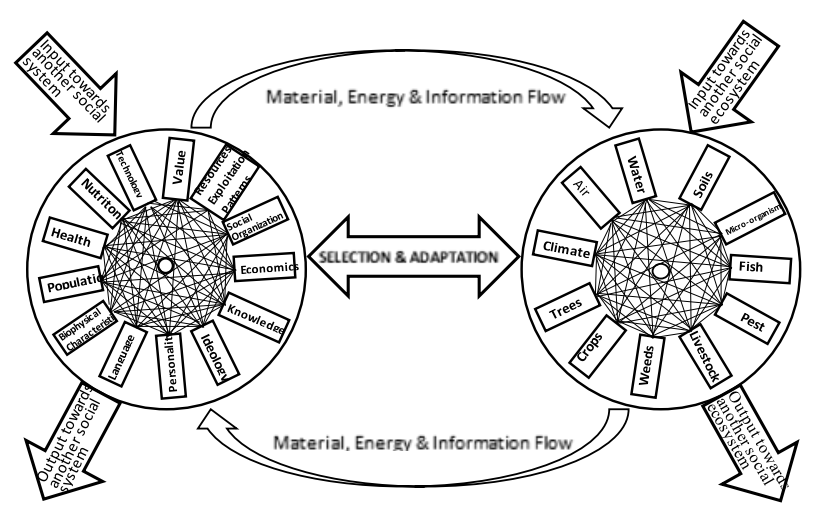

Figure 2. Social system-ecosystem interaction model by Rambo (1983) [42].

The increase in population and the rate of conversion of paddy fields, especially in Java, has encouraged the development of peat swamp lands to support agricultural development, especially food crops on a large scale. On the other hand, peatland management that is not based on the inherent nature and characteristics of the swamp itself has created physical, chemical and biological problems that lead to ecological disasters of peatland fires [7], [43], [44]. 


\subsection{Disaster Literacy Among Young Peatlands Farmers in Central Kalimantan}

The literature related to community interactions and peatland ecosystems above shows that people living in peat ecosystem areas basically have a legacy of traditional knowledge about peatland management. This knowledge includes how to clear peatlands, how to grow crops, manage drainage and the types of vegetation planted. The Dayak Ngaju people generally carry out controlled burning in the preparation of land with firebreaks in the form of digging trenches and clearing all grass, wood, litter around an area of 3-6 meters [34]. Then build a handil system for water management and select local plant types that are adaptive to peatlands [45]. Meanwhile, disaster mitigation is carried out by paying attention to natural signs to determine when the dry season and rainy season enter. The dry season is marked by tamarind fruit that begins to flower, guava flowers begin to bloom, rasau on the riverbanks also starting to flower, the appearance of cranes, buffalo tuntung, patiuk birds, sesulit birds and many fish are found at the river mouth. The rainy season is marked by the fish starting to lay eggs, the root tips turning white (Baputih) and the tamarind fruit turning red. Included in disaster mitigation, in this case, is burning using a timing technique and burning sequence. Regarding the timing of burning, it is generally carried out in August or September according to the climatic conditions that occur in that year. If the dry season is longer, the burning process can be carried out in late September or early October [33].

However, massive peatland conservation has resulted in degradation of the peat ecosystem which is exacerbated by climate change, so that local wisdom no longer applies to peatland management. Currently, people find it very difficult to determine the rainy season or dry season even though they see these natural signs [33].

Therefore, referring to the literacy model from Brown et al., (2014) which states that disaster literacy consists of 4 continuum levels, namely understanding (level 1), application (level 2), communication (level 3) and criticism (level 4) and the literature related to the literacy of peatland management based on local knowledge above, it can be concluded that the literacy of farmers in Central Kalimantan in the past has reached level 3. They have traditional knowledge about peatland management which includes how to clear peatlands, how to cultivate crops, managing drainage and the types of vegetation planted (level 1), applying this knowledge in the management of the farm (level 2) and then passing this knowledge on to the next generation (level 3).

However, with conditions where the level of ecosystem degradation is high and climate change is exacerbated as is happening now, youth farmers on peatlands can no longer maintain the same level of literacy as the previous generation (level 3). They are required to be able to criticize agricultural management on peatlands according to current conditions (level 4).

According to Daramola et al., (2017) disaster literacy is the acquisition of an understanding of individual and public information related to disasters before a disaster occurs so that it is able to help them during and after a disaster [46]. This involves building knowledge in individuals and communities about the nature of environmental hazards and risks, the possible causes and consequences of disasters, and the conditions that make people vulnerable to disasters. This strategy is usually applied through public education that is focused on disaster problems and aims to change public behavior so as to encourage identifying and reducing hazards and risks in their environment [47].

In developed countries, public education on disaster management designed to prepare the population for disasters is provided by both governmental and nongovernmental aid organizations [26]. However, this is not the case in developing countries, as low levels of disaster education have contributed significantly to the vulnerability of their populations during disasters [48]. According to Susanto (2020) there are still many miscommunications related to programs initiated by the central, regional and community governments in efforts to restore peat ecosystems in Indonesia, which has resulted in rejection due to a lack of socialization and understanding of the peat ecosystem [49]. Sawerah (2015) also stated that the level of farmer participation in the implementation of land fire prevention was categorized as very low and the attitude of farmers towards land management without burning tended to be negative due to their lack of knowledge about the peat ecosystem [50]. And Tabenu (2019) states that the adaptive capacity of communities using forest resources to climate change and land fire disasters is also classified as lacking even though they have repeatedly experienced fires [51]. Lack of knowledge about environmentally friendly agricultural and plantation systems has caused haze disasters to occur every year in Indonesia. Therefore, public education is needed in efforts to prevent fire [28], [29].

\section{Conclusion}

Communities living in peatland areas usually have a legacy of traditional knowledge about peatland management, including how to clear peatland, how to cultivate crops, manage drainage and the types of vegetation planted. The Dayak Ngaju people carry out controlled burning in land preparation, usually with firebreaks in the form of digging trenches and clearing all grass, wood, litter around the 3-6 meter wide area. Then build a handil system for water management and choose local types of plants that are adaptive to peatlands. Meanwhile, disaster mitigation is carried out by paying attention to natural signs.

However, massive peatland conservation has resulted in degradation of the peat ecosystem which is exacerbated by climate change, so that local wisdom no longer applies to peatland management. Referring to the literacy model from Brown et al., (2014) which states that disaster literacy consists of 4 continuum levels, namely understanding (level 1), application (level 2), communication (level 3) and criticism (level 4), then Farmers. in Central Kalimantan in the past reached level 3. They have traditional knowledge about peatland 
management, apply and pass this knowledge on to future generations. However, due to ecosystem degradation and climate change, young peatland farmers cannot simply maintain the same level of literacy as the previous generation (level 3). They are required to be able to criticize agricultural management on peatlands according to current conditions (level 4).

Empowering young farmers who are actively involved in peatland management to reduce the risk of disasters from peatland fires is absolutely necessary. This can be done by increasing the level of disaster literacy based on local wisdom followed by an understanding of the characteristics of peatlands and the implications of climate change on their ecosystem.

\section{References}

1. M. Noor, Debat Gambut: Ekonomi, Ekologi, Politik dan Kebijakan. Gadjah Mada University Press, 2016.

2. A. Hoscilo, S.E. Page, K.J. Tansey, J. O. Rieley, "Effect of Repeated Fires on Land-cover Change on Peatland in Southern Central Kalimantan, Indonesia, from 1973 to 2005, ” Int. J. Wildl. Fire, vol. 20, no. 4,( 2011), Accessed: Sep. 30, 2020. [Online]. Available: https://booksc.xyz/book/37407276/5d8c96.

3. R. Dennis, J. Mayer, J. Aplegate, "Fire, people and pixels: linking social science and remote sensing to understand underlying causes and impacts of fires in Indonesia, ” Hum. Ecol., vol. 33, no. 4, pp. 465-504, (2005).

4. J. Wösten, E. Clymans, S. E. Page, J. O. Rieley, and S. H. Limin, "Peat-water interrelationships in a tropical peatland ecosystem in Southeast Asia," Catena, vol. 73, no. 2, pp. 212-224, (2008).

5. Novitasari, J. Sujono, S. Harto, A. Maas, R. Jayadi, "Pengaruh karakteristik gambut terdegradasi terhadap kebakaran lahan gambut (Studi kasus lahan gambut PLG Blok A di Kalimantan Tengah), " Prosiding Seminar Nasional Lingkungan Lahan Basah Volume 3 Nomor 2, (2018).

http://snllb.ulm.ac.id/prosiding/index.php/snllblit/article/view/77/75\# (accessed Sep. 28, 2020).

6. M. Ramdhan, “Analisis Persepsi Masyarakat Terhadap Kebijakan Restorasi Lahan Gambut di Kalimantan Tengah," Risal. Kebijak. Pertan. dan Lingkungan, Rumusan Kaji. Strateg. Bid. Pertan. dan Lingkung., vol. 4, no. 1, pp. 60-72, (2017), doi: 10.20957/jkebijakan.v4i1.20066.

7. M. Noor, Kebakaran Lahan Gambut : dari Asap sampai Kanalisasi. Yogyakarta: Gadjah Mada University Press, 2019.

8. H.-D. V. Boehm, F. Siegert, "Ecological impact of the one million hectare rice project in Central Kalimantan, Indonesia, using remote sensing and GIS, " in 22nd Asian conference on remote sensing, (2001), vol. 9, pp. 3-10.
9. A. Langner and F. Siegert, "Spatiotemporal Fire Occurrence in Borneo Over a Period of 10 Years, " Glob. Chang. Biol., vol. 15, no. 1, pp. 4862, (2009).

10. S. E. Page, F. Siegert, J. O. Rieley, H. D. V. Boehm, A. Jaya, S. Limin, "The amount of carbon released from peat and forest fires in Indonesia during 1997, ” Nature, vol. 420, no. 6911, pp. 6165, Nov. (2002), doi: 10.1038/nature01131.

11. S. E. Page, J. O. Rieley, Ø. W. Shotyk, and D. Weiss, "Interdependence of peat and vegetation in a tropical peat swamp forest," in Changes and Disturbance in Tropical Rainforest in South-East Asia, World Scientific, (1999), pp. 161-173.

12. S. E. Page, A. Hoscilo, K. J. Tansey, and J. O. Rieley, "Effect of repeated fires on land-cover change on peatland in southern Central Kalimantan, Indonesia, from 1973 to 2005, ” Int. J. Wildl. Fire, vol. 20, no. 4, p. 578, Jul. (2011), doi: 10.1071/WF10029.

13. BRG, "Laporan Tahunan Mengawali Restorasi Gambut Indonesia, ” Badan Restor. Gambut, 2016.

14. BRG, Renstra BRG 2016-2020. Jakarta: Badan Restorasi Gambut, 2016.

15. R. Afrian and Z. R. Islami, "Peningkatan potensi mitigasi bencana dengan penguatan kemampuan literasi kebencanaan pada masyarakat Kota Langsa, ” J. Pendidik. Geogr. Kajian, Teor. dan Prakt. dalam Bid. Pendidik. dan Ilmu Geogr., vol. 24, no. 2, pp. 132-144, 2019.

16. S.G. Marlyono, F. Urfan, “Optimalisasi kecerdasan spasial untuk meningkatkan kesiapsiagaan bencana, ” Dec. (2019). Accessed: Jul. 19, 2020. [Online]. Available: http://publikasi.fkipunsam.org/index.php/semnas2019/article/view/114

17. E. P. Purwandari, E. W. Winarni, D. Andreswari, D. Andrian, "Animasi Edukasi Kesiapsiagaan Gempa Bumi Sebagai Sumber Literasi Bencana," in Seminar Nasional Teknologi Informasi Dan Komunikasi (SEMNASTIK) X PalembangIndonesia, Oct. (2018), vol. 1, no. 1, pp. 750-756, Accessed: Jul. 20, 2020. [Online]. Available: www.wartabencana.com.

18. W. M. Adiputra, "Literasi Media dan Interpretasi atas Bencana, ” J. Ilmu Sos. dan Ilmu Polit., vol. 11, no. 3, pp. 287-414, Mar. (2008), doi: 10.22146/JSP.10992.

19. O. Handayani, Y. Yustina, S. Suwondo, “Korelasi antara Pengetahuan dengan Sikap Ilmiah Pencegahan Kebakaran Lahan dan Hutan pada Peserta Didik di Mtsn Bukit Batu Kabupaten Bengkalis, Riau.” Riau University, (2016).

20. Iskandar, A. Saleh, I. Ardyawin, M. R. Rizqan, I. Kurniani, "Sosialisasi Tanggap Bencana Pada Masyarakat Melalui Pendekatan Literasi Media di Labuhan Haji Kabupaten Lombok Timur, ” J. Character Educ. Soc., vol. 2, no. 2, pp. 55-60, Jul. (2019), doi: 10.31764/jces.v3i1.1549. 
21. F. Khairunnisak, "Jangkauan Media, Pengetahuan, dan Sikap Siaga Bencana di Daerah Rawan Bencana, Kabupaten Bandung, ” Institut Pertanian Bogor, (2014).

22. G. Priyowidodo and J. E. Luik, “Communicating Disaster Mitigation Literacy to Coastal Communities in Pacitan Indonesia, ” Dec. (2013), Accessed: Jul. 14, 2020. [Online]. Available: http://www.iasir.net.

23. N. M. R. A. Gelgel, "Media Sosial dan Literasi Kebencanaan di Bali," Interak. J. Ilmu Komun., vol. 9, no. 1, pp. 19-30, May (2020), doi: 10.14710/interaksi.9.1.19-30.

24. F. Yuliani, A. Rahman, "Metode Restorasi Gambut dalam Konteks Mitigasi Bencana Kebakaran Lahan Gambut dan Pemberdayaan Masyarakat," Nov. (2018). doi: 10.33007/INF.V4I2.1460.G867.

25. W. N. Carter, Disaster Management: A Disaster Manager's Handbook. Asian Development Bank, (2008).

26. L. M. Brown, J. N. Haun, L. Peterson, “ $A$ proposed disaster literacy model, " in Disaster Medicine and Public Health Preparedness, (2014), vol. 8, no. 3, pp. 267-275, doi: 10.1017/dmp.2014.43.

27. D. Lawrence, W. H. Schlesinger, "Changes in soil phosphorus during 200 years of shifting cultivation in Indonesia, " Ecology, vol. 82, no. 10, pp. 2769-2780, (2001).

28. N. Pangaribuan, "Restorasi Lahan Gambut Untuk Mencegah Bencana Ekosistem Global,” Semin. Nas. FST Univ. Terbuka 2019, (2019).

29. C. Oktiana, "Hubungan Tingkat Pengetahuan Konservasi Lahan Gambut dengan Tingkat Partisipasi Petani dalam Upaya Pencegahan Kebakaran Lahan Gambut di Desa Gambut Jaya Kecamatan Sungai Gelam KABUPATEN MUARO JAMBI TAHUN 2017," Universitas Negeri Semarang, (2017).

30. S. Kanbara, W. Ozawa, Y. Ishimine, N. R. Ngatu, Y. Nakayama, S. Nojima, "Operational Definition of Disaster Risk-Reduction Literacy, ” Heal. Emerg. Disaster Nurs., vol. 3, no. 1, pp. 1-8, 2016, doi: 10.24298/hedn.2014-0016.

31. K. Tanaka, "The impact of disaster education on public preparation and mitigation for earthquakes: A cross-country comparison between Fukui, Japan and the San Francisco Bay Area, California, USA," Appl. Geogr., vol. 25, no. 3, pp. 201-225, Jul. (2005), doi: 10.1016/j.apgeog.2005.07.001.

32. Z. M. Muktaf, "Studi Literasi Bencana dalam Perspektif Ilmu Komunikasi, , (2017).

33. A. Akbar, "Studi Kearifan Lokal Penggunaan Api Persiapan Lahan: Studi Kasus di Hutan Mawas, Kalimantan Tengah,” J. Penelit. Sos. dan Ekon. Kehutan., vol. 8, no. 3, pp. 211-230, (2011), doi: 10.20886/jsek.2011.8.3.211-230.
34. E. Hadiwijoyo, B. H. Saharjo, and I. Putra, "Kearifan Lokal Masyarakat Dayak Ngaju Di Kalimantan Tengah Dalam Melakukan Penyiapan Lahan Dengan Pembakaran Local Wisdom of Dayak Ngaju in Central Kalimantan on Land Preparation By Using Fire, " Silvikultur Trop. - J. Trop. Silvic. Sci. Technol., vol. 8, no. 1, pp. 1-8, (2017).

35. P. S. Bellwood, Prasejarah kepulauan IndonesiaMalaysia. Gramedia Pustaka Utama, (2000).

36. I. Yogi, "Padi Gunung Pada Masyarakat Dayak, Sebuah Budaya Bercocok Tanam Penutur Austronesia (Melalui Pendekatan Etnoarkeologi), " in Jurnal Forum Arkeologi, (2018), vol. 31

37. N. Hujjatusnaini, “Konservasi Kawasan Hutan di Lamandau Dengan Konsep Bioremiadiasi dan Adat Dayak Kaharingan (Tajahan, Kaleka, Sapan Pahewan, dan Pukung Himba), ” Bioedukasi, vol. 4, no. 2, Oct. (2016), Accessed: Jul. 13, 2020. [Online]. Available:

http://ejournal.unkhair.ac.id/index.php/bioedu/artic le/view/163.

38. Wahyu, Nasrullah, "Malacak, Manatak, Maimbul: Kearifan Lokal Petani Dayak Bakumpai dalam Pengelolaan Padi di Lahan Rawa Pasang Surut," Komunitas Int. J. Indones. Soc. Cult., vol. 4, no. 1, p. 168895, (2012).

39. M. Megawati, S. Zainal, B. Burhanuddin, "Kearifan Lokal Masyarakat Dalam Pelestarian Lahan Gambut di Kecamatan Sungai Kakap Kabupaten Kubu Raya, ” J. Hutan Lestari, vol. 8, no. 1, (2020).

40. A. S. Keraf, Etika Lingkungan Hidup, Pertama. Jakarta: Kompas, (2010).

41. J. Iskandar, Ekologi Perladangan di Indonesia. Jakarta: Penerbit Djambatan, (1992).

42. J. Iskandar, Ekologi Manusia dan Pembangunan Berkelanjutan, Edisi Revisi. Bandung: Program Studi Magister Ilmu Lingkungan Universitas Padjadjaran, (2017).

43. M. F. Barchia, Gambut: Agroekosistem dan Transformasi Karbon, 2nd ed. Yogyakarta: Gadjah Mada University Press, (2012).

44. Sukandarrumidi, Rekayasa gambut, briket batubara, dan sampah organik: usaha memanfaatkan sumberdaya alam yang terpinggirkan. Gadjah Mada University Press, (2009).

45. M. Noor, Pertanian lahan gambut, potensi dan kendala. Kanisius, (2001).

46. O. Daramola, O. Odunsi, and O. Olowoporoku, "The Corridor to Survival: Assessment of Disaster Management Literacy in a Developing Country, " Environ. Qual. Manag., vol. 27, no. 2, pp. 15-24, (2017).

47. C. B. Field, V. Barros, T. F. Stocker, and Q. Dahe, Managing the risks of extreme events and disasters to advance climate change adaptation: special 
report of the intergovernmental panel on climate change. Cambridge University Press, (2012).

48. O. A. Olowoporoku, "Assessment of Household Disaster Management Literacy in Osogbo, Nigeria," (2017).

49. D. Susanto, “Implementasi Kebijakan Restorasi Gambut di Kalimantan Selatan dari Persfektif Komunikasi Kebijakan (Studi Kasus di Kecamatan Candi Laras Utara Kabupaten Tapin)."

Universitas Islam Kalimantan MAB, (2020).

50. S. Sawerah, "Partisipasi Petani Dalam Pelaksanaan Pencegahan Kebakaran Lahan Gambut (Kasus Di Kabupaten Mempawah Provinsi Kalimantan Barat)., " Bogor Agricultural University (IPB), (2015).

51. O. Tabenu, "Peran dan Relasi Aktor dalam Resiliensi Komunitas Menghadapi Bencana Kebakaran Hutan.” IPB University, (2019). 